\title{
Hydrocephalus Caused by H3N2 Type A Influenza Virus or Cerebellopontine Angle Schwannoma?
}

Sir,

We report the case of a 51-year-old woman who was admitted to the emergency department at the University Hospital Center Zagreb, Croatia, presenting with progressively worsening headache, nausea, dizziness, and ataxia. Ten days before the onset of symptoms she was discharged from another hospital, where she was treated with oseltamivire after type A influenza virus had been isolated from her saliva. An urgent brain magnetic resonance imaging (MRI) showed enlarged ventricles with radiographic features of hypertensive hydrocephalus. In addition, a medium-sized $(2.5 \mathrm{~cm} \times 3 \mathrm{~cm})$ tumor, characterized radiologically as schwannoma, was noted in the left cerebellopontine angle, without signs of fourth ventricle compression or aqueductal stenosis [Figure 1a-d]. Lumbar puncture results were not suggestive of meningitis/encephalitis-cerebrospinal fluid (CSF) biochemistry values were within reference ranges. Immediately before the planned surgery, the patient became somnolent, with inadequate verbal responses, and developed a series of generalized tonic-clonic seizures, after which she was transferred to the intensive care unit. External ventricular drainage (EVD) was inserted preoperatively. Gross total tumor resection with facial nerve preservation was performed through a retrosigmoid craniotomy, using intraoperative evoked potential monitoring. Histopathology confirmed that the tumor was a schwannoma (predominantly Antoni A tissue). Influenza virus type $\mathrm{A}, \mathrm{H} 3 \mathrm{~N} 2$ subtype, was identified in the CSF obtained from the EVD using the polymerase chain reaction method (considered effective and sensitive). ${ }^{[1]}$ Postoperative brain MRI showed a small tumor remnant and persisting ventricular enlargement. There were no radiological signs of encephalitis [Figure 2a-c]. The patient did not tolerate EVD weaning, requiring the placement of a ventriculoperitoneal CSF shunt with a programmable valve system (at $110 \mathrm{~cm} \mathrm{H}_{2} \mathrm{O}$ ). Follow-up computed tomography showed a reduction in the size of the ventricular system [Figure 2d]. As her condition improved, she was transferred to a neurosurgical unit and subsequently dismissed from hospital neurologically improved: Glasgow Coma Scale 15, House-Brackmann grade II facioparesis, without headaches or other neurological symptoms.

To the best of our knowledge (PubMed search, August 2017, no language restrictions: "hydrocephalus" AND "influenza"), only one similar case of H3N2 type A influenza virus-related hydrocephalus has been described in the literature. De Santis et al. ${ }^{[2]}$ reported a case of influenza-related cerebellitis with secondary obliteration of the sylvian aqueduct and triventricular hydrocephalus in a patient with serious systemic comorbidites who was discharged in a persisting coma state. Possibe pathogenetic mechanisms underlying the 


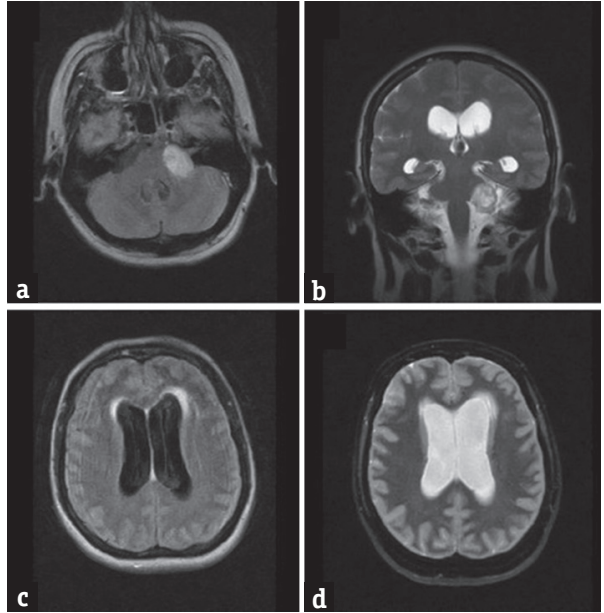

Figure 1: ( $\mathrm{a}$ and $\mathrm{b}$ ) Fluid-attenuated inversion recovery axial and T2-coronal magnetic resonance imaging images showing left cerebellopontine schwannoma without significant compression on fourth ventricle. (c and d) Fluid-attenuated inversion recovery and T2-axial magnetic resonance imaging images presenting enlargement of lateral ventricles with signs of subependymal effusions

association between viral infections and hydrocephalus include ependymal destruction and aqueductal stenosis through selective ependymal cell infection, and periventricular and periaqueductal gliosis. ${ }^{[3]}$ Different influenza virus-related central nervous system infections have been described in the literature, including fatal encephalopathy, acute cerebellitis and severe neurological sequealae. ${ }^{[4,5]}$ Our patient had coincidental vestibular schwannoma, a condition known to be associated with changes in CSF dynamics and hydrocephalus - it is possible that the schwannoma acted as a predisposing condition and the viral infection triggered the acute hydrocephalus.

Influenza-associated hydrocephalus is an extremely rare condition that can trigger serious neurological disorders. Patients with comorbid conditions are at a greater risk of developing such complications.

\section{Financial support and sponsorship}

Nil.

\section{Conflicts of interest}

There are no conflicts of interest.

Jakob Nemir, Ivan Domazet, Klara Brgic, Natasa Kovac', Goran Mrak

Department of Neurosurgery, School of Medicine, ${ }^{1}$ Department of Anesthesiology and Intensive Care, University Hospital Center Zagreb, Zagreb, Croatia

Address for correspondence: Dr. Ivan Domazet, Department of Neurosurgery, School of Medicine, University Hospital Center Zagreb, Kispaticeva 12, 10000 Zagreb, Croatia. E-mail: ivandomazet@yahoo.com

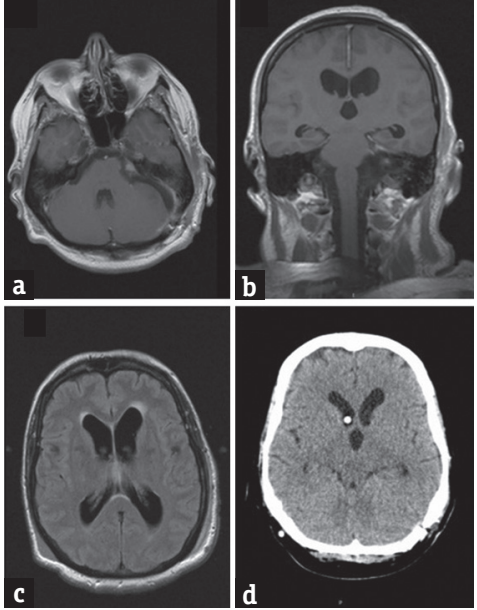

Figure 2: (a-c) Control magnetic resonance imaging after tumor removal, showing small tumor remnant in internal acoustic porus and persistence of ventricular enlargement. (d) Control after implanted a programmable ventriculoperitoneal shunt showing ventricular size reduction and appropriate position of proximal catheter

\section{REFERENCES}

1. Steininger C, Kundi M, Aberle SW, Aberle JH, Popow-Kraupp T. Effectiveness of reverse transcription-PCR, virus isolation, and enzyme-linked immunosorbent assay for diagnosis of influenza A virus infection in different age groups. J Clin Microbiol 2002;40:2051-6.

2. De Santis P, Della Marca G, Di Lella G, Cavallaro F. Neurological picture. Sub-acute hydrocephalus in a patient with influenza A (H3N2) virus-related cerebellitis. J Neurol Neurosurg Psychiatry 2012;83:1091-2.

3. Johnson RT. Hydrocephalus and viral infections. Dev Med Child Neurol 1975; 17:807-16

4. Olgar S, Ertugrul T, Nisli K, Aydin K, Caliskan M. Influenza a-associated acute necrotizing encephalopathy. Neuropediatrics 2006;37:166-8

5. Toovey S. Influenza-associated central nervous system dysfunction: A literature review. Travel Med Infect Dis 2008;6:114-24.

This is an open access article distributed under the terms of the Creative Common Attribution-NonCommercial-ShareAlike 3.0 License, which allows others to remix, tweak and build upon the work non-commercially, as long as the author is credited and the new creations are licensed under the identical terms.

\begin{tabular}{|l|l|}
\hline \multicolumn{2}{|c|}{ Access this article online } \\
\hline Quick Response Code: & Website: \\
\hline
\end{tabular}

How to cite this article: Nemir J, Domazet I, Brgic K, Kovac N, Mrak G. Hydrocephalus caused by H3N2 type A influenza virus or cerebellopontine angle schwannoma?. J Neurosci Rural Pract 2017;8:692-3.

C 2017 Journal of Neurosciences in Rural Practice | Published by Wolters Kluwer - Medknow 